\title{
PENGUATAN KEDUDUKAN MAHKAMAH KEHORMATAN DEWAN SEBAGAI PERADILAN ETIKA
}

\author{
Sekar Anggun Gading Pinilih \\ Fakultas Hukum Universitas Diponegoro \\ Jl. Prof. Soedarto, S.H, Tembalang, Semarang \\ sekar_anggun@live.undip.ac.id
}

\begin{abstract}
Supervision of the ethics of board members is something that needs to be done so that their duties and authority can run well. Therefore, efforts are needed to strengthen the Honorary Court of the Council as a supervisor and at the same time adjudicate the ethical violations of board members. Strengthening efforts are needed for the position, membership and authority of the Honorary Court of the Council so that in the future it can become an ethics court and become independent and accountable. In addition, it is necessary to establish a law that regulates the ethics of public officials, and regulates an integrated supervisory institution so that there is no difference in perceptions of the implementation of the supervisory function by the supervisory institutions that are internal in each state institution.
\end{abstract}

Keywords: Supervision; Ethics; Honorary Court Council.

\begin{abstract}
Abstrak
Pengawasan terhadap etika dari anggota dewan merupakan suatu hal yang perlu dilakukan agar tugas dan kewenangannya dapat berjalan dengan baik. Oleh karena itu, diperlukan upaya penguatan terhadap Mahkamah Kehormatan Dewan sebagai pengawas sekaligus mengadili pelanggaran-pelanggaran etika dari anggota dewan. Upaya penguatan yang diperlukan terhadap kedudukan, keanggotaan dan kewenangan Mahkamah Kehormatan Dewan agar kedepannya dapat menjadi sebuah peradilan etika dan dapat bersifat mandiri dan akuntabel. Selain itu, perlu dibentuk sebuah undang-undang yang mengatur etika pejabat publik, dan mengatur pula lembaga pengawasan yang bersifat terpadu sehingga tidak terjadi perbedaan persepsi atas pelaksanaan fungsi pengawasan oleh lembaga-lembaga pengawasan yang bersifat internal di masing-masing lembaga negara.
\end{abstract}

Kata Kunci: Pengawasan; Etika; Mahkamah Kehormatan Dewan.

\section{A. Pendahuluan}

Alinea ke-4 Pembukaan UUD 1945 menyatakan bahwa pemerintahan negara yang hendak dibentuk adalah pemerintahan Negara Republik Indonesia yang berkedaulatan rakyat. Artinya, bahwa dari awal kemerdekaan, rakyat sudah menghendaki bahwa Negara Indonesia adalah negara yang kekuasaan tertingginya berada di tangan rakyat, atau yang dikenal dengan pemerintahan demokrasi. Amanat ini kemudian dituangkan ke dalam Pasal 1 ayat (2) UUD NRI Tahun 1945 yang berbunyi: "Kedaulatan adalah di tangan rakyat dan dilaksanakan menurut Undang-Undang Dasar". Kemudian, terdapat penambahan ayat pada Pasal 1 yaitu ayat (3) yang menyatakan bahwa Indonesia adalah negara hukum. Hal ini berarti adanya penegasan bahwa Negara Indonesia adalah negara demokrasi yang berdasarkan atas hukum (Palguna, 2013). 
Gagasan akan suatu negara hukum di Indonesia, apakah menggunakan gagasan rechtsstaat dari tradisi civil law atau pengaruh gagasan rule of law dari tradisi common law, sebenarnya telah menjadi salah satu paham konstitusi, yang lazim dikenal dengan konstitusionalisme, telah tersurat dalam semua konstitusi yang pernah berlaku di Indonesia, mulai dari UUD 1945, UUD RIS, UUD 1950 hingga UUD 1945 setelah perubahan. Bahkan, gagasan negara hukum (the rule of law) telah dimasukkan dalam GBHN dan Repelita pada masa orde baru (Rachman, 2019). Negara hukum Indonesia yang berdasarkan Pancasila secara praksis bertujuan ingin mewujudkan gagasan negara hukum yang lebih memanusiakan harkat dan martabat manusia Indonesia, bahkan sebagai bangsa dalam komunitas negara dan dunia internasional.

Hal ini dapat terwujud dengan pemerintahan yang bersih dan bebas dari korupsi, kolusi dan nepotisme. Pemerintahan yang bersih dan bebas dari korupsi, kolusi dan nepotisme dapat terwujud apabila seluruh pejabat negara dan pejabat publik menjadikan etika sebagai pedoman dalam menjalankan tugas, fungsi, dan wewenangnya. Kajian mengenai hukum dan etika/moral sekarang ini menjadi suatu yang penting untuk dibicarakan. Khususnya dengan adanya perkembangan baru yaitu adanya gejala mempositiviskan etika, dimana ketentuan mengenai nilai etika dan standar perilaku ideal mulai dikonkretkan penegakannya dalam praktik. Hal ini menjadikan norma etika tumbuh dan berkembang seperti norma hukum yang selama ini dikenal. Menegakkan norma etika dalam kehidupan, khususnya dalam penyelenggaraan kekuasaan negara, tidaklah mudah. Sejak memasuki era reformasi, norma etika menjadi perhatian penting terhadap pejabat negara dan pejabat publik, terutama anggota dewan.

Dewasa ini, kepercayaan publik terhadap anggota dewan semakin menurun. Hal ini disebabkan oleh banyaknya oknum anggota dewan yang bermasalah dengan etika dan hukum. Akibatnya dapat menurunkan dan merusak martabat, kehormatan dan kredibilitas lembaga parlemen itu sendiri. Melihat begitu pentingnya kedudukan etika, namun dalam praktik justru dilanggar sendiri oleh anggota dewan. Seringkali terjadi pelanggaran etika yang dilakukan oleh oknum anggota dewan, seperti melakukan perbuatan tercela, penyimpangan terhadap aturan, penyalahgunaan wewenang, dan masih banyak lagi. Tindakan yang demikian tentunya dapat dipersoalkan secara etika karena mengandung potensi pelanggaran hukum.

Selain itu, seringkali anggota dewan tidak dapat menempatkan statusnya sebagai alat negara. Mereka justru menggunakan statusnya tersebut sebagai alat kekuasaan/politik. Hal ini disebabkan karena posisi anggota dewan yang dapat mempengaruhi dalam pengambilan kebijakan negara. Gambaran demikian menunjukkan bahwa etika masih belum dipahami dan dijalankan sepenuhnya oleh para anggota dewan, sehingga dapat menjadi sebuah kegagalan dalam mewujudkan pemerintahan yang bersih. Oleh karena itu, pada dasarnya persoalan utama bangsa Indonesia tidak hanya terletak pada aturannya saja tetapi juga pada etika dan moralitas pejabat negara dan pejabat publiknya.

Dengan demikian, perlu adanya kelembagaan etik parlemen yang independen dan profesional guna menjaga wibawa parlemen yang ditunjukkan oleh anggota dewan, terutama dalam kondisi kekuasaan parlemen modern yang begitu luas tentunya semakin besar peluang untuk terjadinya penyalahgunaan kewenangan (abuse of power) (Rusnan, 2017), yang kemudian oleh Undang-Undang Nomor 22 Tahun 2003 tentang Susunan dan Kedudukan MPR, DPR, DPD, dan DPRD dibentuklah lembaga penegak etik yang disebut dengan Badan Kehormatan. Badan Kehormatan ini diganti menjadi Mahkamah Kehormatan Dewan setelah adanya perubahan terhadap Undang-Undang tentang MPR, DPR, DPD dan DPRD, yaitu oleh 
Undang-Undang Nomor 17 Tahun 2014 tentang MPR, DPR, DPD, dan DPRD.

Menurut Jimly Asshidiqie, salah satu ciri dari negara hukum adalah adanya pembatasan kekuasaan dalam penyelenggaraan negara (Asshiddiqie, 2013). Adanya pembatasan kekuasaan negara bertujuan agar tidak terjadi kesewenang-wenangan dari penguasa. Negara Indonesia telah membagi kekuasaan di dalam konstitusi menjadi tiga kekuasaan, yaitu kekuasaan legislatif, eksekutif dan yudikatif, namun pelaksanaan kekuasaan tersebut tidak mengacu secara murni dari teori Montesquie, tetapi kekuasaan negara yang berdasarkan sistem check and balances.

Demokrasi yang dijalankan oleh Indonesia adalah demokrasi perwakilan sebagaimana yang menjadi amanat dari sila ke-4 Pancasila yang menyatakan bahwa "kerakyatan yang dipimpin oleh hikmat kebijaksanaan dalam permusyawaratan/perwakilan”. Hal ini terlihat sampai dengan perubahan ketiga UUD 1945 yang dihasilkan rumusan bahwa perwakilan rakyat sebagai konsekuensi Indonesia sebagai negara demokrasi ada pada lembaga Dewan Perwakilan Rakyat (DPR) dan Dewan Perwakilan Daerah (DPD). Rumusan yang demikian secara jelas menggambarkan bahwa lembaga perwakilan rakyat melalui sistem dua kamar (sistem bikameral), namun melihat pada Pasal 3 ayat (1) perubahan ketiga dan Pasal 2 ayat (1) perubahan ke empat UUD 1945 muncul kembali lembaga MPR sebagai lembaga tersendiri, di luar DPR dan DPD. Hal ini menggambarkan bahwa sistem perwakilan Indonesia tidak lagi menjadi sistem dua kamar, tetapi menjadi tiga kamar/sistem trikameral (MPR, DPR, dan DPD) dengan keanggotaan, tugas dan wewenangnya masing-masing (Purnama, 2014). Namun, adanya amandemen UUD 1945 telah mengubah kedudukan dan fungsi lembaga MPR, yang awalnya sebagai pelaksana kedaulatan rakyat satu-satunya.

Sebagai negara demokrasi, sistem perwakilan menjadi suatu sistem yang dianggap paling rasional, sehingga banyak negara demokrasi mengadopsi hal itu. Sistem perwakilan dapat menjadi sarana penting untuk mengakomodir masyarakat yang beragam (plural), sehingga dapat mereduksi tindakan dominasi dan anarkhi dari satu kelompok kepada kelompok lainnya (Budiardjo, 2005). Oleh karena itu, representasi keterwakilan dalam sebuah lembaga perwakilan menjadi penting, karena diperintahkan oleh rakyat untuk menampung aspirasi-aspirasi rakyat. Di Indonesia, lembaga legislatif merupakan lembaga yang membuat undang-undang. Anggota-anggota lembaga tersebut dianggap mewakili rakyat, maka dari itu lembaga tersebut sering dinamakan Dewan Perwakilan Rakyat. Dewan Perwakilan Rakyat inilah yang akan membuat kebijakan-kebijakan sesuai aspirasi rakyat dalam bentuk undang-undang (Yani, 2018).

Konstitusi Indonesia telah menegaskan melalui ciri-cirinya, bahwa Indonesia menganut sistem pemerintahan presidensial. Dalam konsep sistem pemerintahan presidensial, yang utama adalah bahwa kedudukan antara lembaga eksekutif dan legislatif adalah sama kuat. Untuk lebih jelasnya berikut ciri ciri sistem pemerintahan presidensial menurut Scott Mainwaring sebagai berikut: 1) Posisi Presiden sebagai kepala negara sekaligus kepala pemerintahan; 2) Presiden dan legislatif dipilih oleh rakyat; 3) Lembaga eksekutif bukan bagian dari lembaga legislatif, sehingga tidak dapat diberhentikan oleh lembaga legislatif kecuali melalui mekanisme pemakzulan; dan, 4) Presiden tidak dapat membubarkan lembaga parlemen. (Saraswati, 2012)

Melihat pada ciri-ciri tersebut, maka terlihat bahwa kedudukan Dewan Perwakilan Rakyat adalah kuat. Dewan Perwakilan Rakyat tidak dapat membubarkan Presiden, begitu juga sebaliknya, Dewan Perwakilan Rakyat tidak dapat dibubarkan pula oleh Presiden. Keberadaan lembaga Dewan Perwakilan Rakyat dalam ketatanegaraan Indonesia setelah amandemen UUD 1945 memiliki 
peran yang besar. Dewan Perwakilan Rakyat difungsikan tidak hanya sebagai lembaga legislatif, tetapi sebagai lembaga penyeimbang dari kekuasaan eksekutif. Dalam menjalankan tugas dan wewenangnya, Dewan Perwakilan Rakyat memiliki alat-alat kelengkapannya, salah satunya adalah Badan Kehormatan, yang diganti dengan Mahkamah Kehormatan Dewan.

Lembaga penegak etik lazim dibentuk pada sistem lembaga parlemen modern. Dibentuknya lembaga penegak etik didasarkan pada latar belakang bahwa parlemen yang berkembang menjadi semakin baik memungkinkan untuk diawasi setiap perilaku yang dilakukannya dalam menjalan tugasnya sebagai anggota parlemen. Pengawasan dapat dilakukan oleh internal maupun eksternal parlemen. Pengawasan oleh eksternal dapat dilakukan oleh rakyat atau partai politiknya, tetapi pengawasan oleh internal dilakukan oleh internal parlemen itu sendiri. Pengawasan oleh internal parlemen inilah yang pada akhirnya dibentuklah sebuah lembaga yang disebut dengan Badan Kehormatan, yang kemudian diubah namanya menjadi Mahkamah Kehormatan Dewan (Rusnan, 2017). Mahkamah Kehormatan Dewan inilah yang mengawasi perilaku atau etika dari para anggota parlemen agar tidak melakukan pelanggaran kode etik selama menjalankan tugasnya.

Keberadaan Mahkamah Kehormatan Dewan sangatlah penting untuk menegakkan etika dari anggota-anggota legislatif. Mahkamah Kehormatan Dewan perlu dibentuk sebagai peradilan etika di lingkungan lembaga legislatif. Semakin banyaknya pelanggaran etik yang dilakukan oleh anggota-anggota legislatif yang diberikan sanksi yang lemah, bahkan terjadi pembiaran. Peneliti Forum Masyarakat Peduli Parlemen Indonesia melakukan penelitian terhadap pelanggaran-pelanggaran etik yang dilakukan oleh anggota DPR dalam masa bakti DPR tahun 2014-2019. Sebagai contoh, kasus Setyo Novanto dan Fadli Zon yang telah melakukan pelanggaran kode etik secara berat sebanyak 3 kali, namun keduanya tidak diberikan sanksi oleh Mahkamah Kehormatan Dewan ("Noktah Hitam Pelanggaran Etik DPR 2014-2019: dari Fadli Zon hingga Setnov," n.d.). Tidak hanya anggota lembaga legislatif di pusat, anggota lembaga legislatif daerah juga banyak melakukan pelanggaran etika, contohnya terjadi korupsi massal yang dilakukan oleh anggota DPRD Kota Malang. Sebanyak 41 orang dari 45 anggota DPRD Kota Malang telah ditetapkan tersangka oleh KPK ("Peristiwa Fakta Memprihatinkan Korupsi Berjamaah Anggota Dewan di Kota Malang," n.d.). Hal ini tentunya tidak hanya melanggar hukum tetapi juga telah mencerminkan etika yang buruk dari para anggota legislatif di Indonesia.

Kedudukan Mahkamah Kehormatan Dewan bersifat tetap dan bertugas melakukan pencegahan, pengawasan, penyelidikan dan penindakan atas pengaduan pelanggaran yang dilakukan oleh anggota DPR, sebagaimana yang diatur pada Pasal 119 Undang-Undang Nomor 17 Tahun 2014 tentang MPR, DPR, DPD, dan DPRD. Meskipun pembentukan Mahkamah Kehormatan Dewan merupakan sebuah upaya yang baik, namun menimbulkan problema filosofis, yuridis dan sosiologis. Problema filosofis muncul manakala Mahkamah Kehormatan Dewan masih bekerja secara konvensional dan belum dikonstruksikan sebagai lembaga peradilan sebagaimana dipahami di dunia hukum. Mahkamah Kehormatan Dewan adalah alat kelengkapan parlemen yang bersifat tetap sebagaimana perintah dari Undang-Undang Nomor 17 Tahun 2014. Namun, kedudukan Mahkamah Kehormatan Dewan berada di internal lembaga DPR, sehingga tidak independen. Padahal semangat pembentukan Mahkamah Kehormatan Dewan ini adalah sebagai peradilan etika yang bertugas untuk menindak pelanggaran etik yang dilakukan oleh anggota dewan. Kedudukan Mahkamah Kehormatan Dewan yang tidak independen, maka mempengaruhi kewenangannya sebagai peradilan etika, khususnya dalam 
hal penjatuhan sanksi yang lemah bahkan adanya pembiaran.

Problema yuridis muncul manakala belum ada pengaturan yang mendudukkan Mahkamah Kehormatan Dewan sebagai peradilan etik yang mandiri dan akuntabel dimana hal ini tidak sesuai dengan semangat pembentukan Mahkamah Kehormatan Dewan. Bahkan, Undang-Undang Nomor 17 Tahun 2014 mengatur bahwa Mahkamah Kehormatan Dewan diisi oleh beberapa perwakilan fraksi partai dalam keanggotaannya, sehingga terbuka peluang adanya konflik kepentingan antar Mahkamah Kehormatan Dewan dengan anggota-anggota dewan itu sendiri. Sedangkan, problema sosiologis muncul manakala persidangan etik yang dilakukan oleh Mahkamah Kehormatan Dewan bersifat tertutup sehingga tidak transparan, serta pasifnya Mahkamah Kehormatan Dewan dalam menjalankan tugas dan wewenangnya padahal kasus-kasus pelanggaran etik oleh anggota legislatif semakin banyak.

Berdasarkan uraian di atas, menarik untuk dikaji mengenai seberapa penting perlunya memposisikan Mahkamah Kehormatan Dewan sebagai peradilan etika dalam rangka meningkatkan penegakan etik lembaga legislatif. Penelitian ini akan merekomendasikan konstruksi ke depan dari lembaga Mahkamah Kehormatan Dewan sebagai peradilan etika terbuka. Oleh karena itu, maka permasalahan yang akan penulis kaji adalah: 1) Mengapa perlu dilakukan penguatan terhadap kedudukan Mahkamah Kehormatan Dewan sebagai peradilan etika?; 2) Bagaimana konsep penguatan kedudukan Mahkamah Kehormatan Dewan ke depannya sebagai peradilan etika?

\section{B. Pembahasan}

\section{Urgensi Penguatan Mahkamah Kehormatan Dewan sebagai Peradilan Etika}

Etika menunjukkan adanya nilai baik atau buruk dari manusia. Konsep nilai adalah awal dari moralitas. Tindakan yang sesuai akal dan kehendak bebas dikombinasi dengan tujuan nilai baik atau buruk menghasilkan tindakan moral. Tindakan moral ini menghasilkan yang namanya normal moralitas. Tindakan moral adalah transformasi dari nilai-nilai yang dimiliki manusia. Moralitas tidak lebih dari sekedar penyesuaian dengan aturan yang mengatur kehidupan manusia: yaitu aturan akal (Jr, 1953). Moral adalah yang mengenai batin manusia. Jika memahami hukum sebagai undang-undang, maka moral adalah norma dasar sebagai dasar yang terakhir sebagai pondasi segala hukum dan pelaksanaannya. Norma hukum itu dapat dirumuskan dalam bentuk suatu kaidah hukum yang dianggap sebagai yang tertinggi dalam bidang hukum. Artinya, undang-undang dan semua norma hukum harus sesuai dengan norma-norma moral, karena sebenarnya hukum termasuk moral.(Huijbers, 1986)

Etika itu lebih luas daripada hukum. Setiap pelanggaran hukum dapat dikatakan juga melanggar etika, tetapi sesuatu melanggar etika, belum tentu melanggar hukum. Melihat begitu pentingnya kedudukan etika, namun dalam praktik justru dilanggar sendiri oleh anggota dewan. Kode etik yang telah dilanggar tidak hanya berakibat pada kinerja lembaga legislatif, tetapi juga mengurangi integritas dan kredibilitas lembaga legislatif di mata masyarakat. Perlunya kelembagaan etik parlemen yang independen dan profesional guna menjaga wibawa parlemen yang ditunjukkan oleh anggota parlemen, terutama dalam kondisi kekuasaan parlemen modern yang begitu luas tentunya semakin besar peluang untuk terjadinya penyalahgunaan kewenangan (abuse of power) (Rusnan, 2017), yang kemudian oleh Undang-Undang Nomor 22 Tahun 2003 tentang Susunan dan Kedudukan MPR, DPR, DPD, dan DPRD dibentuklah lembaga penegak etik yang disebut dengan Badan Kehormatan. Badan Kehormatan ini diganti menjadi Mahkamah Kehormatan Dewan setelah adanya perubahan terhadap UndangUndang tentang MPR, DPR, DPD dan DPRD, yaitu oleh Undang-Undang Nomor 
17 Tahun 2014 tentang MPR, DPR, DPD, dan DPRD (selanjutnya disebut UU MD3).

Kedudukan Mahkamah Kehormatan Dewan dalam UU MD3 bersifat tetap. Hal ini menjadi sesuatu yang baik dibandingkan lembaga penegak etik lainnya yang masih bersifat ad hoc maupun belum diatur menggunakan undang-undang. Sebagai contoh, Dewan Etik MK, dimana kedudukan Dewan Etik MK bersifat tetap tetapi tidak diatur dengan undang-undang, melainkan diatur melalui Peraturan MK. Kedudukan yang tidak diatur dengan undang-undang, maka memungkinkan dapat dibubarkan dengan mencabut Peraturan MK tersebut. Berbeda halnya jika diatur melalui undangundang, maka kedudukannya akan menjadi lebih kuat karena pembubaran atau pengubahan bentuk lembaga tersebut harus melibatkan DPR dan Presiden sebagai pembentuk undang-undang (Huda, dkk, 2018). Oleh karena itu, secara formalyuridis, kedudukan Mahkamah Kehormatan Dewan disebut lebih baik dibandingkan lembaga penegak etik yang serupa. Namun, kedudukan bersifat tetap ini juga bukan tanpa permasalahan, karena menjadi tidak mandiri. Kedudukan Mahkamah Kehormatan Dewan menjadi bagian dari lembaga DPR.

Hal ini dapat dilihat dari kedudukan kelembagaan Mahkamah Kehormatan Dewan itu sendiri yang merupakan salah satu alat kelengkapan DPR (bersifat internal), sebagaimana yang diatur dalam Pasal 119 UU MD3. Kedudukan yang demikian menunjukkan bahwa Mahkamah Kehormatan Dewan menjadi bagian dari lembaga DPR sehingga potensi terjadinya konflik kepentingan sangatlah besar. Hal ini tentunya akan mempengaruhi pelaksanaan tugas dan fungsi dari Mahkamah Kehormatan Dewan sebagai peradilan etika yang mandiri dan tidak mendapat intervensi dari manapun.

Selain itu, keanggotaan Mahkamah Kehormatan Dewan berasal dari para fraksi yang ada dalam lembaga legislatif. Artinya, bahwa anggota Mahkamah Kehormatan Dewan berasal dari anggota dewan itu sendiri, tidak ada anggota dari luar dewan, misalnya melibatkan anggota masyarakat atau akademisi. Hal ini terbuka adanya intervensi dalam pengambilan keputusan oleh Mahkamah Kehormatan Dewan, mengingat yang diperiksa adalah anggotaanggota dewan itu sendiri. Selain itu, adanya rasa segan atau tidak enak dari anggota Mahkamah Kehormatan Dewan kepada anggota dewan yang notabene adalah teman sejawat dalam lembaga legislatif sehingga membuka adanya ketidaktegasan dalam menjatuhkan sanksi kepada para anggota dewan yang melanggar kode etik.

Kedudukan lembaga ini tidak hanya dapat dilihat pada keanggotaan yang tidak bersifat mandiri saja tetapi juga berkaitan dengan kewenangan yang diberikan oleh undang-undang kepada Mahkamah Kehormatan Dewan. Mahkamah Kehormatan Dewan diberikan kewenangan penuh layaknya lembaga penegak/peradilan etik yang sifatnya mandiri. Hal ini dapat terlihat pada kewenangan untuk dapat memeriksa dugaan pelanggaran etik maupun hukum menggunakan alat-alat bukti yang memiliki derajat serupa dengan sistem peradilan pada umumnya. Selain itu, ketika Mahkamah Kehormatan Dewan mengeluarkan keputusan terdapat irah-irah "Demi Keadilan Berdasar Ketuhanan Yang Maha Esa", sebagaimana yang terdapat dalam badan peradilan (Qamariah Novita, 2016). Hal ini tentunya menimbulkan ambiguitas karena di satu sisi Mahkamah Kehormatan Dewan berperan sebagai lembaga peradilan tetapi di sisi lain putusan dari Mahkamah Kehormatan Dewan bersifat politis karena menjadi salah satu alat kelengkapan dari lembaga legislatif.

Berkaitan dengan penegakan kode etik juga menemukan permasalahan. Sidang yang dilakukan oleh Mahkamah Kehormatan Dewan bersifat tertutup, kecuali dinyatakan terbuka oleh sidang Mahkamah Kehormatan Dewan. Menurut penulis, dengan sidang dilakukan tertutup, maka tidak adanya transparansi dalam penegakan kode etik tersebut karena masyarakat tidak dapat secara langsung 
melihat proses persidangan oleh Mahkamah Kehormatan Dewan kepada pelanggar yaitu anggota dewan itu sendiri. Selain itu, dengan sidang tertutup, maka pelanggar yang dilaporkan telah melanggar kode etik tidak dapat membela diri secara terbuka. Dalam hal ini, maka keadilan etika tidak mungkin terwujud. Sidang yang bersifat tertutup pasti hanya akan menimbulkan dugaan-dugaan saja padahal dalam konteks ini berkaitan dengan etika seseorang yang berakibat pada kredibilitasnya sebagai anggota dewan. Berdasarkan beberapa kelemahan terkait dengan kedudukan, tugas dan wewenang Mahkamah Kehormatan Dewan, maka perlu dilakukan pembaharuan melalui perubahan mengenai kedudukan, keanggotaan, tugas dan kewenangan dari Mahkamah Kehormatan Dewan di lingkungan lembaga legislatif.

Dengan dilakukan pembaharuan mengenai kedudukan, keanggotaan, tugas dan kewenangan Mahkamah Kehormatan Dewan, maka dapat melahirkan peluang juga untuk menjadikan Mahkamah Kehormatan Dewan sebagai peradilan etika yang bersifat mandiri. Sejauh ini organorgan yang berfungsi melakukan pengawasan masih bekerja secara konvensional dan belum dikonstruksikan sebagai lembaga peradilan sebagaimana dipahami di dunia hukum. Keadilan seolaholah hanya dikaitkan dengan dunia hukum saja, tidak dengan etika sehingga tidak pernah terpikirkan bahwa norma etika juga berguna untuk menegakkan nilai-nilai keadilan. Pandangan rule of ethics belum dijalankan oleh lembaga-lembaga yang menegakannya. Lembaga-lembaga yang menegakkannya pun dilaksanakan secara tertutup. Oleh karena itu, jika perkembangan di dunia sekarang ini sudah sampai pada tahap perkembangan etika yang bersifat terbuka, maka kedepannya perlu ada suatu proses peradilan etika yang bersifat terbuka pula. Di Indonesia, sejauh ini hanya ada satu lembaga peradilan etika yang bersifat terbuka yaitu Dewan Kehormatan Penyelenggara Pemilihan Umum di lingkungan eksekutif. Oleh karena itu,
Mahkamah Kehormatan Dewan di lingkungan legislatif pun juga dapat berpeluang sama untuk menjadi peradilan etika, sejalan dengan nomenklaturnya sebagai sebuah Mahkamah.

\section{Konsep Penguatan Kedudukan Mahkamah Kehormatan Dewan ke Depannya sebagai Peradilan Etika}

Keberadaan sistem pengawasan terhadap lembaga negara merupakan suatu hal yang penting, karena setiap kekuasaan selalu mengandung potensi untuk disalahgunakan atau dilakukan secara sewenang-wenang atau dilaksanakan dengan melampaui wewenang Hal ini dapat terjadi karena dua hal, pertama, kekuasaan mengandung hak dan wewenang, kedua, hak dan wewenang, memberi posisi lebih baik terhadap subjek yang dituntut atau dalam hal ini pencari keadilan, setiap kekuasaan tanpa mekanisme pengawasan (hukum) secara cepat atau lambat kekuasaan tersebut disalahgunakan. Baligante menyatakan "geen macht zonder toiziht" dan Lord Acton menyatakan "power tends to corrups". (Manan, 2009)

UU MD3 menempatkan Mahkamah Kehormatan Dewan sebagai salah satu alat kelengkapan DPR yang bersifat tetap. Mahkamah Kehormatan Dewan berfungsi untuk mengawasi, menegakkan dan meningkatkan moral anggota-anggota dewan sehingga pelanggaran yang dilakukan para anggota dewan dapat dikontrol dan ditekan sedemikian terjadinya pelanggaranpelanggaran moral tersebut. Meskipun kedudukan Mahkamah Kehormatan Dewan ini belum secara maksimal mengurangi pelanggaran-pelanggaran etik dari anggota dewan, namun perannya begitu penting.

Berkaitan dengan adanya kelemahankelemahan dalam Mahkamah Kehormatan Dewan, maka perlu adanya pembaruan. Menurut penulis, pembaruan yang perlu dilakukan, sebagai berikut:

a. Kedudukan kelembagaan

Mahkamah Kehormatan Dewan merupakan salah satu perangkat dalam 
kelembagaan DPR (bersifat internal). Hal ini dapat dilihat dari ketentuan Pasal 119 UU MD3. Mahkamah Kehormatan Dewan ditempatkan sebagai bagian dari kelembagan DPR adalah tidak tepat. Mahkamah Kehormatan Dewan yang merupakan lembaga yang bersifat tetap dan berfungsi melakukan pengawasan etika anggota-anggota dewan berpotensi tidak mampu menjalankan tugas dan wewenangnya karena adanya konflik kepentingan. Idealnya, kelembagaan Mahkamah Kehormatan Dewan berada di luar lembaga DPR. Dengan demikian, perlu dipertimbangkan untuk mengatur lembaga Mahkamah Kehormatan Dewan melalui peraturan tersendiri, misalnya dengan membentuk undangundang khusus tentang peradilan etika lembaga di lingkungan legislatif, eksekutif dan yudikatif.

b. Keanggotaan

Melihat pada UU MD3 bahwa anggota Mahkamah Kehormatan Dewan berasal dari fraksi-fraksi yang ada. Hal ini tentunya akan mempengaruhi independensi tugas dan wewenang Mahkamah Kehormatan Dewan untuk menindaklanjuti pelanggaran-pelanggaran etik yang ditemukan. Akan ada rasa 'ewuh pekewuh' di antara anggota dewan itu sendiri karena akan menindak koleganya sendiri. Oleh karena itu, menurut penulis diperlukan anggota dari luar fraksi yang lebih bersifat independen, misalnya para akademisi dan anggota masyarakat lainnya.

c. Tugas dan Wewenang

Kedudukan lembaga Mahkamah Kehormatan Dewan yang berada di bawah lembaga DPR juga mempengaruhi tugas dan wewenangnya sebagaimana yang diatur dalam UU MD3 Pasal 124 ayat (4). Pasal 124 ayat (4) mengatur bahwa Mahkamah Kehormatan Dewan menyampaikan pemberitahuan kepada pimpinan DPR atas keputusan tindak lanjut penanganan pelanggaran sebagaimana dimaksud pada Pasal 124 ayat (3). Hal ini tentunya dapat mempengaruhi kemandirian Mahkamah Kehormatan Dewan dalam melakukan penindakan atas pelanggaran-pelanggaran yang ditemukan karena harus memberitahukannya kepada pimpinan DPR dimana pimpinan DPR berpotensial pula menjadi pihak terlapor atau terduga melakukan pelanggaran etika, sehingga di sini memunculkan adanya konflik kepentingan. Pengaturan yang demikian menurut penulis menjadi tidak ideal. Seharusnya Mahkamah Kehormatan Dewan dijauhkan dari hal-hal yang bersifat administratif yang berhubungan langsung maupun tidak langsung dengan DPR.

d. Sidang Pemeriksaan

Sidang pemeriksaan oleh Mahkamah Kehormatan Dewan dilaksanakan secara tertutup dalam praktik. Hal ini mengacu dari ketentuan Pasal 132 ayat (1) UU MD3 yang memerintahkan bahwa sidang dilakukan secara tertutup. Pemeriksaan yang bersifat tertutup menjadi tidak tepat, mengingat tidak adanya transparansi dan partisipasi publik untuk memantau pelaksanaan pemeriksaan. Oleh karena itu, menurut penulis perlu adanya sidang pemeriksaan secara terbuka, kecuali untuk pelanggaran-pelanggaran yang berkaitan dengan asusila. Pemeriksaan secara terbuka akan lebih menjamin proses penegakan etika yang bersifat transparan dan akuntabel sehingga penegakan etika dapat benar-benar dipercaya oleh masyarakat. Namun, untuk pelanggaran-pelanggaran asusila harus ditutup karena berkaitan dengan hal-hal yang bersifat privasi, sensitif 
dan tidak pantas dilihat oleh masyarakat, sesuai dengan nilai kemanusiaan yang adil dan beradab.

Adanya pembaruan mengenai
kedudukan, keanggotaan, tugas dan
wewenang sebagaimana yang penulis
sampaikan di atas, akan meningkatkan
independensi kelembagaan Mahkamah
Kehormatan Dewan itu sendiri. Mahkamah
Kehormatan Dewan haruslah menjadi
lembaga yang independen dan tidak
bergantung pada lembaga DPR. Diharapkan
ke depannya Mahkamah Kehormatan
Dewan dapat menjadi peradilan etik yang
independen dan berfungsi mengawasi dan
menjaga perilaku-perilaku dari anggota
dewan secara mandiri. Independensi antar
lembaga negara merupakan sesuatu yang
penting dalam negara demokrasi Indonesia,
khususnya Indonesia telah mendesain bahwa
negara demokrasi Indonesia adalah negara
demokrasi yang berdasarkan mekanisme
check and balances.
berkelindan dengan independensi dari masing-masing lembaga negara. Jimly Asshidiqie menyatakan ada 3 (tiga) bentuk independensi dalam lembaga negara, yaitu:

1. Independensi institusional, yaitu independensi yang tercermin dalam mekanisme hubungan antar institusi/lembaga negara.

2. Independensi fungsional, yaitu independensi yang tercermin dalam proses pengambilan keputusan, yakni bebas dalam menetapkan kebijakan pokok, dan bebas dalam menetapkan instrumen kebijakan yang tidak ditetapkan sendiri; dan

3. Independensi administratif, yaitu merdeka dalam menentukan kebijakan administratif untuk mendukung kedua independensi di atas, berupa independensi anggaran dan independensi pegawai.(Asshiddiqie, 2008)

Berdasarkan hal tersebut di atas, maka upaya untuk menguatkan kelembagaan sistem pengawasan etika lembaga DPR menjadi suatu hal yang harus diwujudkan agar independensi dari lembaga Mahkamah Kehormatan Dewan sebagai pengawas etika dapat benar-benar terwujud.

\section{Simpulan}

Pengawasan terhadap etika dari anggota dewan merupakan suatu hal yang perlu dilakukan agar tugas dan kewenangannya dapat berjalan dengan baik. Oleh karena itu, diperlukan upaya penguatan terhadap Mahkamah Kehormatan Dewan sebagai pengawas sekaligus mengadili pelanggaranpelanggaran etika dari anggota dewan. Konsep penguatan Mahkamah Kehormatan Dewan yang perlu dilakukan, meliputi aspek kedudukan kelembagaan dan keanggotaannya, dimana kedudukan Mahkamah Kehormatan Dewan sebaiknya terpisah dari lembaga DPR agar menjadi peradilan etika, dan dapat bersifat mandiri dan akuntabel dengan adanya pengaturan tersendiri, serta keanggotaan Mahkamah Kehormatan Dewan sebaiknya tidak hanya berasal dari para fraksi di lembaga DPR, tetapi juga harus melibatkan orang-orang yang independen maupun melibatkan masyarakat. Selain itu, perlu pula perbaikan pada tugas dan wewenang Mahkamah Kehormatan Dewan, yaitu tidak perlu menunggu persetujuan pimpinan DPR dalam melakukan penindakan-penindakan terhadap pelanggaran etika dari anggota dewan, serta dalam sidang pemeriksaan sebaiknya dilakukan secara terbuka agar terdapat mekanisme pengawasan pula dari masyarakat luas, kecuali untuk pelanggaranpelanggaran etika yang berkaitan dengan asusila.

Dengan banyaknya pelanggaranpelanggaran etika yang dilakukan oleh pejabat publik di lingkungan badan legislatif, eksekutif maupun yudikatif, maka menurut penulis sebaiknya ke depan perlu adanya sebuah undang-undang tentang etika pejabat publik dimana undang-undang tersebut mengatur hal-hal apa saja yang dibolehkan dan tidak diperbolehkan untuk dilakukan oleh para pejabat publik, dan 
mengatur pula lembaga pengawasan yang bersifat terpadu sehingga tidak terjadi perbedaan persepsi atas pelaksanaan fungsi pengawasan oleh lembaga-lembaga pengawasan yang bersifat internal di masing-masing lembaga negara.

\section{DAFTAR PUSTAKA}

Asshiddiqie, J. (2008). Pokok-Pokok Hukum Tata Negara Indonesia. Jakarta: BIP Gramedia.

Asshiddiqie, J. (2013). Pengantar Ilmu Hukum Tata Negara. Jakarta: Rajawali Pers.

Budiardjo, M. (2005). Dasar-Dasar Ilmu Politik. Jakarta: PT Gramedia.

Huda, dkk, N. (2018). Rekonstruksi Kedudukan dan Kewenangan Dewan Etik Hakim Konstitusi Sebagai Upaya Memperkuat Integritas Hakim Konstitusi. Jakarta.

Huijbers, T. (1986). Filsafat Hukum dalam Lintasan Sejarah. Yogyakarta: Kanesius.

Jr, A. S. (1953). Law and Morality. Marquette Law Review, 36(3), 321-322.

Manan, B. (2009). Menegakkan Hukum Suatu Pencarian. Jakarta: Asosiasi Advokat Indonesia.

Noktah Hitam Pelanggaran Etik DPR 20142019: dari Fadli Zon hingga Setnov. (n.d.). Retrieved from https://news.detik.com/berita/d4726413/noktah-hitam-pelanggaranetik-dpr-2014-2019-dari-fadli-zonhingga-setnov

Palguna, I. D. G. (2013). Pengaduan
Konstitusional (Constitutional Complaint): Upaya Hukum Terhadap Pelanggaran Hak-Hak Konstitusional Warga Negara. Jakarta: Sinar Grafika.

Peristiwa Fakta Memprihatinkan Korupsi Berjamaah Anggota Dewan di Kota Malang. (n.d.). Retrieved from https://www.merdeka.com/peristiwa/fak ta-memprihatinkan-korupsi-berjamaahanggota-dewan-di-kota-malang.html

Purnama, E. (2014). Lembaga Perwakilan dan Checks and Balances dalam Kekuasaan Negara. Kanun Jurnal Ilmu Hukum, XVI(63), 260.

Qamariah Novita, N. (2016). Penyelesaian Pelanggaran Kode Etik Anggota Dewan Perwakilan Rakyat. Jurnal Katalogis, 4(12), 144.

Rachman, I. N. (2019). Politik Hukum Yudisial dalam Perencanaan dan Pembangunan Sistem Hukum Nasional. Universitas Diponegoro.

Rusnan. (2017). Kedudukan Mahkamah Kehormatan Dewan Dalam Sistem Parlemen Di Indonesia. Jurnal IUS: Kajian Hukum Dan Keadilan, V(3), 366.

Saraswati, R. (2012). Desain Sistem Pemerintahan Presidensial Yang Efektif. Jurnal Masalah-Masalah Hukum, $\quad 41(1), \quad 138$. https://doi.org/10.14710/mmh.41.1.201 2.137-143

Yani, A. (2018). Analisis Kontruksi Struktural dan Kewenangan DPR dalam Fungsi Legislasi Berdasarkan UndangUndang Dasar 1945. Jurnal Konstitusi, 15(2), 349. 